\title{
Sykdom i Nidarosdomen?
}

Opp mot hvelvet i Nidarosdomen skjuler det seg en rekke kunstverk som vanligvis ikke er tilgjengelige for allmennheten. Flere av steinskulpturene fremstiller fabeldyr og andre skremmende eksistenser. I dette selskapet kunne man tenke seg at menneskeansikter også skulle inngi frykt og angst. Forestiller de syke mennesker?

at:

Engelsk oversettelse på www.tidsskriftet.no

Vinteren 2011 ble deler av Nidarosdomen rengjort og pusset opp for første gang siden midten av 1920-årene $(1,2)$. Det foregikk i oktogonen, det åttekantete rommet reist over stedet der Olav den hellige skal være begravet. Et stillas i seks høyder erstattet høyalteret for å nå opp til sluttsteinen i hvelvingen 20 meter til værs. På vei opp og ned stillaset fikk førsteforfatter anledning til å beundre kunstverk som har vært utilgjengelig for allmennheten siden forrige rengjøring. Ifølge arkeolog Øystein Ekroll, lederen for restaureringsarbeidene, vil det gå et nytt hundreår før noen igjen kommer så nær disse kunstskattene (2).

\section{Menneskeansikter og fabeldyr}

Man ville kanskje forvente å møte fremstillinger av engler og helgener der oppe i høyden. Men de er få. Merkverdige fabeldyr, derimot, ikke minst demoner og andre skumle eksistenser, rår rommet i høyden (2).

Vår interesse samlet seg raskt om en gruppe figurer på en gesimsfrise på tredje høydenivå - en fremstilling av to menneskeansikter og fem fabelfigurer, alle med et skrekkinngytende utseende.

Lengst til venstre er det et mannshode med en narrelue på hodet. Ansiktet er forvridd $i$ en grimase som kan gi mistanke om misdannelse, skade eller alvorlig nevrolo- gisk affeksjon, men det kan også representere alvorlig sinnslidelse eller psykisk utviklingshemming. Til høyre for narren, og til venstre for fabeldyrene, stirrer en gammel, tannløs kvinne rett på oss (fig 1). Sammenstillingen av figurene kan få oss til å tro at kvinnen også var ment å vekke anstøt og angst. Men hva bestiller hun i selskap med sine selsomme naboer, narren og fabeldyrene?

\section{Var hun syk?}

Lite er kjent om kunstverkene i Nidarosdomen, men gesimsfrisen kan dateres ganske nøyaktig. Den kom på plass ved restaureringen etter den første storbrannen i den nybygde domen i 1328. Ettersom alt arbeid stoppet opp med svartedauden (1349-50) (3), vet vi at de kom til i løpet av en 20-årsperiode. Mest sannsynlig var det engelske steinhoggere som laget dem (Øystein Ekroll, personlig meddelelse) (3). Kunne britiske forbilder hjelpe oss videre?

I kirken St. Mary's i landsbyen Burton Lazars i Midt-England, der det på 1100tallet var opprettet et leprahospital til sankt Lasarus' ære (4), finnes et annet steinhode. Forfra har det likhetstrekk med kvinnehodet i Nidarosdomen, selv om det er mer slitt av tidens tann og mindre detaljert og direkte i uttrykket (fig 2). Det engelske kvinnehodet kalles «the leper», og lepradiagnosen er stilt på grunnlag av flere karakteristiske forandringer som særlig er tydelige i profil (5). Kunne kvinnen i Nidarosdomen også være en fremstilling av lepra?

Vi har rådført oss med flere kyndige kolleger innen leprologi og medisinsk historie. De var tvilende til hypotesen. For det første mangler det karakteristiske løveansiktet (facies leonata) som kan opptre når sykdommen har vart lenge. Da er underhuden fylt av små knuter fullpakket av leprabasiller. Dette gir ansiktet et pløsete utseende, med furer som skyldes valker av tykk hud (Gunnar Bjune, personlig meddelelse). Det taler ikke for denne sykdommen at huden tilsynelatende virker glatt og livløs, noe som eventuelt kunne skyldes lammelser i ansiktsmuskulaturen. Tap av tenner er typisk for lepra, men rammer helst fortenner og hjørnetenner i overmunnen. Den dårlige tannstatusen kan like gjerne tolkes som uttrykk for dårlig allmenntilstand $\mathrm{og}$ lav sosial status. Ved lepra synker nesen typisk inn ved neseroten. Det er ikke tilfellet her. Sannsynligvis er skaden på nesetippen forvoldt i ettertid.

Et annet spørsmål gjelder steinhoggerens intensjon og eventuelle kunnskap om den sykdommen som søkes fremstilt, og om det ut fra det vil være mulig å stille rett diagnose $i$ ettertid (Sigurd Sandmo, personlig meddelelse). Så lenge tegnene på sykdommen er
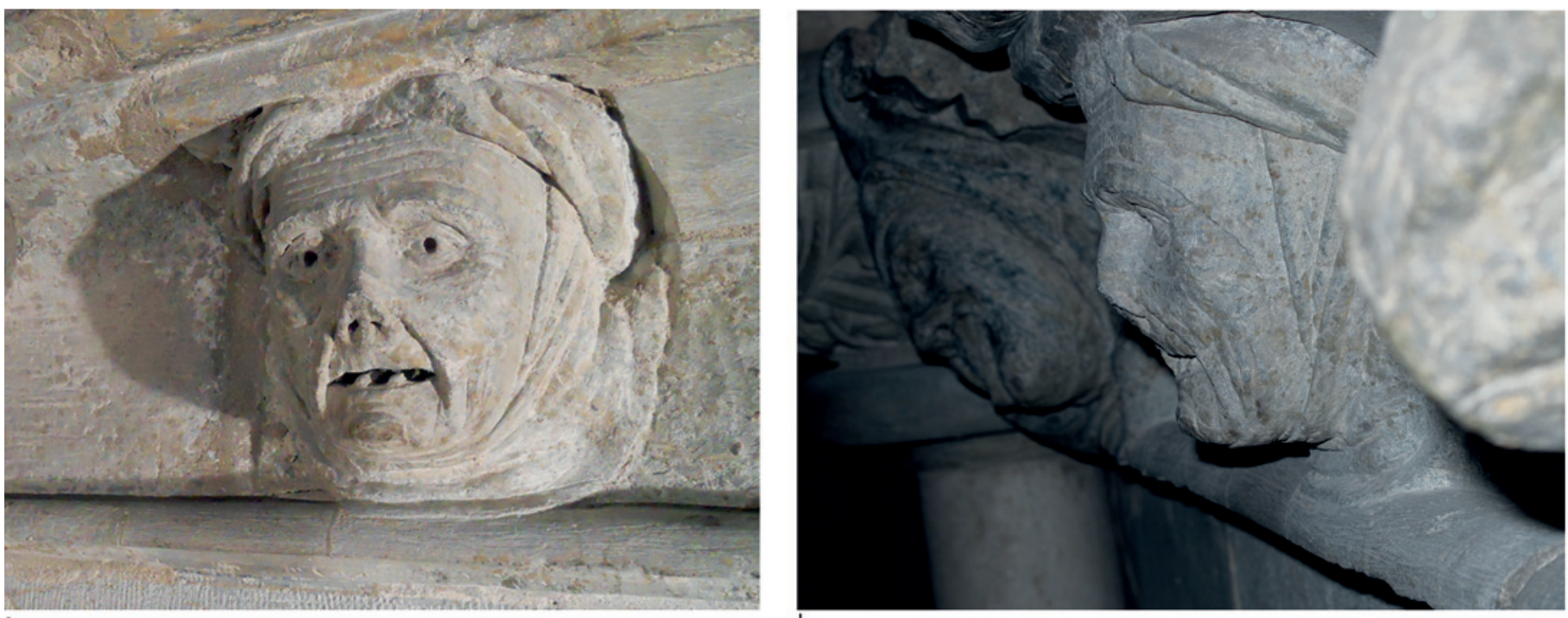

Figur 1 a) Kvinneansiktet en face. Foto Harald Brandtzæg. b) Kvinneansiktet i profil. Foto Øystein Ekroll. Skulpturen er igjen skjult for allmennheten, som en rekke andre verdifulle kunstskatter i Nidarosdomen 


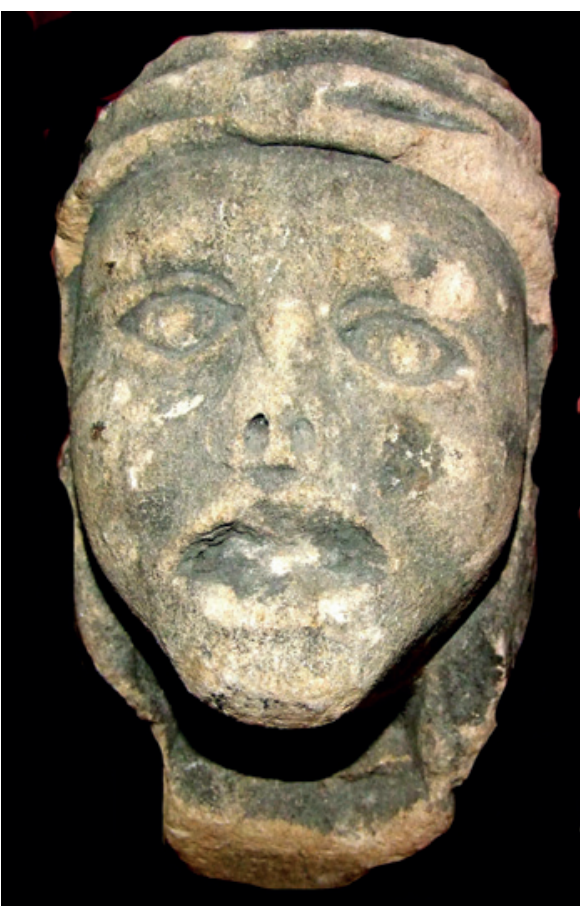

Figur 2 Kvinnehode, kalt «the leper». St. Mary's church, Melton Mowbray, England. Foto Tina Negus

flertydige, blir det desto vanskeligere å komme frem til en presis diagnose og en sikker konklusjon. Intensjonen kan også gå tapt ved at man står overfor et hode i stein.

Stilt overfor et snart 700 år gammelt kunstverk skal man være forsiktig med å stille medisinske diagnoser. Avstandsdiagnostikk er en vanskelig øvelse - i både tid og rom. I tillegg til intensjonen bak kunstverket og en historisk kontekst som er i stadig endring ville en sikker tolking av diagnosen også være avhengig av supplerende kilder (Øivind Larsen, personlig meddelelse). I dette tilfellet kunne det være at en skulptur eller avbildning forekommer

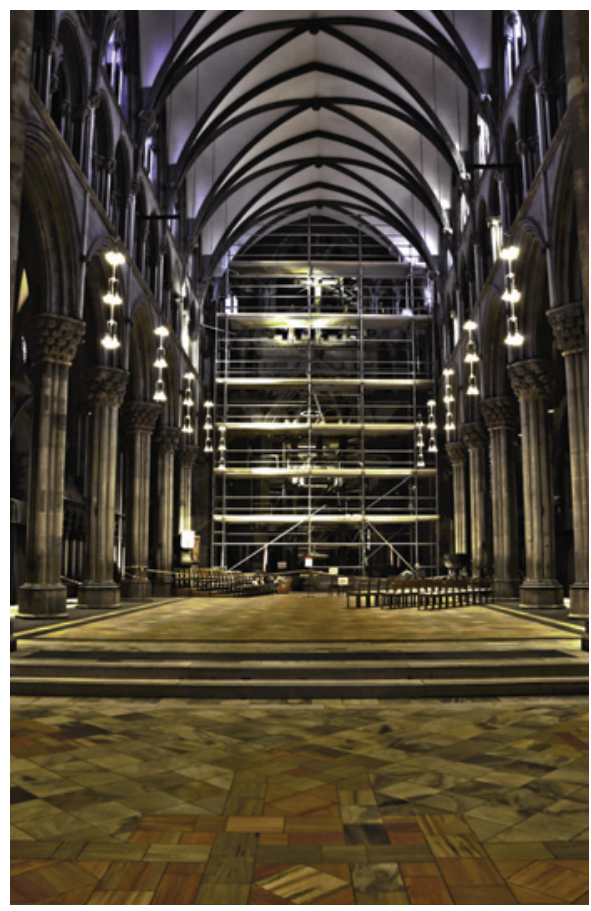

Nidarosdomen, koret og oktogonen (2011). Høyalteret er erstattet med et 20 meter høyt stillas. Foto Nidaros domkirkes restaureringsarbeider

sammen med et helgenbilde der helgenen er knyttet til en bestemt sykdom. Vi kan ikke fremlegge noe i den retning.

\section{Avslutning}

Kvinnehodet i Nidarosdomen forestiller neppe lepra. Hva som kan ha vært steinhoggerens intensjon, forblir i historiens mørke. Også de verdifulle kunstskattene og resultatet av de mange steinhoggernes iherdige arbeid forblir skjult. Slik sett gir det god mening at alle ansatte ved Nidarosdomens restaureringsarbeider etter 25 års innsats får et sølvfat med inskripsjonen «Gud i himmelen ser ditt arbeid» (2).
Geir W. Jacobsen

geir.jacobsen@ntnu.no

Institutt for samfunnsmedisin

Norges teknisk-naturvitenskapelige universitet

\section{Erlend Hem}

Tidsskriftet

Vi takker for velvillig bistand fra Øystein Ekroll (vandring i Nidarosdomen og bilde), for omfattende kommentarer fra Gunnar Bjune, Øivind Larsen, Per Holck og Sigurd Sandmo, og Tina Negus for utlån av bilde fra St. Mary's church, Melton Mowbray.

Geir W. Jacobsen (f. 1945) er professor ved Institutt for samfunnsmedisin, Norges teknisknaturvitenskapelige universitet, og medisinsk redaktør i Tidsskriftet.

Forfatter har fylt ut ICMJE-skjemaet og oppgir ingen interessekonflikter.

Erlend Hem (f. 1970) er dr.med. og assisterende redaktør i Tidsskriftet.

Forfatter har fylt ut ICMJE-skjemaet og oppgir ingen interessekonflikter.

Litteratur

1. Nidarosdomen. Oktogonen. www.nidarosdomen. no/nb-NO/oktogonen/oktogonen.html (1.2.2012).

2. Rogstad B. Kun for Guds øyne. Vårt Land 19.3.2011: $28-30$

3. Krüger S. Elefantene i Nidarosdomen: fra steinhuggerlivet ved St Olavs katedral. Trondheim: Communicatio forlag, 2006.

4. Hem E. Lasarus, lasarett og lasaron. Tidsskr Nor Legeforen 2012; 132: 701

5. Marcombe D, Manchester K. The Melton Mowbray «leper head»: an historical and medical investigation. Med History 1990; 34: 86-91. www.ncbi.nlm.nih.gov/pmc/articles/PMC 1036003 (1.2.2012).

Mottatt 9.2 2012, første revisjon innsendt 27.2 . 2012, godkjent 1.3. 2012. Medisinsk redaktør Petter Gjersvik. 